\title{
IMPLIKASI PERUBAHAN NARATIF DAN SINEMATIK DARI EKRANISASI BLOG “KAMBING JANTAN”
}

\author{
Arami Kasih \\ Lilik Kustanto \\ Endang Mulyaningsih \\ Jurusan Film \& Televisi, Fakultas Seni Media Rekam, Institut Seni Indonesia Yogyakarta \\ Jl. Parangtritis km. 6.5 Yogyakarta Telp. (0274) 381047
}

\begin{abstract}
Film as manifestation of concrete ideas in its development can not be separated from the adaptation phenomenon of ecranisation. The ecranisation that most widely carried out so far is from a novel form. Adaptation from others media both as research and creation is still rare. Therefore, the ecranisation from a blog form that generaly known as online diary can be considered an odd phenomenon. This research describes about the adaptation process of blog "Kambing Jantan" from posts collection in book "Kambing Jantan - Sebuah Catatan Harian Pelajar Bodoh" to film "Kambing Jantan - Sebuah Film Pelajar Bodoh".

In the process of adaptation found narrative and cinematic changes caused by the differences of media characteristics. The signification of changes in this case is dominate by reduction form. On the next level, the changes can be appears in a continuous implications pattern both in narrative and cinematic area. The changes also can have an impact on story orientation.
\end{abstract}

Keywords : ecranisation, blog, film, narrative, cinematic

\begin{abstract}
ABSTRAK
Film sebagai manifestasi gagasan yang kongkrit pada perkembangannya tidak lepas dari fenomena alih wahana ekranisasi. Ekranisasi yang banyak dilakukan sejauh ini adalah pengangkatan dari bentuk novel. Pengangkatan bentuk media lain baik sebagai kajian maupun penciptaan masih terbilang jarang. Oleh sebab itu, ekranisasi dari bentuk blog yang secara umum dikenal sebagai buku harian merupakan fenomena tidak biasa. Penelitian ini membahas proses pengangkatan blog "Kambing Jantan" dari buku kumpulan postingan "Kambing Jantan - Sebuah Catatan Harian Pelajar Bodoh" menjadi film "Kambing Jantan - Sebuah Film Pelajar Bodoh". Pada proses pengangkatan tersebut ditemukan perubahan naratif dan sinematik yang disebabkan oleh perbedaan karakteristik media. Perubahan dalam hal ini terjadi secara signifikan dengan didominasi oleh bentuk pengurangan. Pada tahap lebih lanjut, perubahan tersebut kemudian membentuk pola implikasi berkesinambungan dalam wilayah naratif dan sinematik. Perubahan yang terjadi dalam proses ekranisasi juga berimplikasi terhadap perubahan orientasi cerita.
\end{abstract}

Kata kunci : ekranisasi, blog, film, naratif, sinematik

\section{Pendahuluan}

Film sebagai karya audio- visual pada perkembangannya tidak lepas dari fenomena alih wahana. Istilah alih wahana dipopulerkan oleh Sapardi Djoko Damono yang mengatakan bahwa selain diterjemahkan, sebuah karya juga dapat dialih-wahanakan menjadi jenis karya lain (Damono 2009, 121).
Pada lingkup yang lebih spesifik, fenomena alih wahana ke dalam bentuk film dikenal sebagai ekranisasi. Istilah tersebut berasal dari bahasa Prancis ecran yang berarti layar. Ekranisasi secara bahasa dapat didefinisikan sebagai pelayarputihan, yaitu sebuah proses pengangkatan karya baik seni 
maupun sastra ke dalam bentuk film (Eneste 1991, $60-61)$.

Film sebagai seni adalah sebuah manifestasi gagasan dalam bentuk kongkrit. Film mampu mentransformasi gagasan menjadi sebuah fenomena rasional dalam suatu lingkup ruang dan waktu. Film dalam hal ini dapat mewujud sebagai kesatuan imaji yang mendekati realita (Boggs and Petrie 2008, 4).

Ekranisasi yang cukup banyak dilakukan sejauh ini adalah pengangkatan dari bentuk karya novel. Ekranisasi dari bentuk media lain baik sebagai kajian maupun penciptaan masih sangat jarang dilakukan di Indonesia. Adapun pengangkatan dari bentuk blog yang secara umum dikenal sebagai buku harian personal dalam hal ini merupakan fenomena yang tidak biasa.

Film "Kambing Jantan" adalah film pertama atau barang kali akan menjadi film terakhir yang diekranisasi dari blog di Indonesia. Sebagaimana proses adaptasi novel ke film, pelayarputihan dari blog juga mengalami perubahan signifikan secara naratif dan sinematik. Perubahan tersebut dapat berupa penambahan, pengurangan, dan variasi serta memiliki implikasi.

Berdasarkan latar belakang tersebut maka ditemukan rumusan masalah antara lain: 1) Apa saja perubahan naratif dan sinematik yang terjadi dalam proses ekranisasi dari blog "Kambing Jantan"? 2) Apakah implikasi dari perubahan naratif dan sinematik yang terjadi pada ekranisasi blog “Kambing Jantan”?
Tujuan penelitian ini adalah 1) mendeskripsikan dan menjelaskan apa saja perubahan dalam proses ekranisasi dari blog "Kambing Jantan". 2) Mendeskripsikan implikasi naratif dan sinematik dari perubahan dalam proses ekranisasi blog "Kambing Jantan".

Metode yang digunakan pada penelitian ini adalah metode penelitian gabungan dengan pendekatan deskriptif.

Each methodology can be used to complement the other within the same area of inquiry, since they have different porposes or aims (Susan Stainback dalam Sugiono 2011, 27)

Adapun metode pengambilan data yang digunakan pada penelitian ini adalah observasi yang dilakukan terhadap kedua objek blog dan film; serta metode pengambilan data dokumentasi.

Skema yang digunakan pada penelitian ini adalah sebagai berikut. 


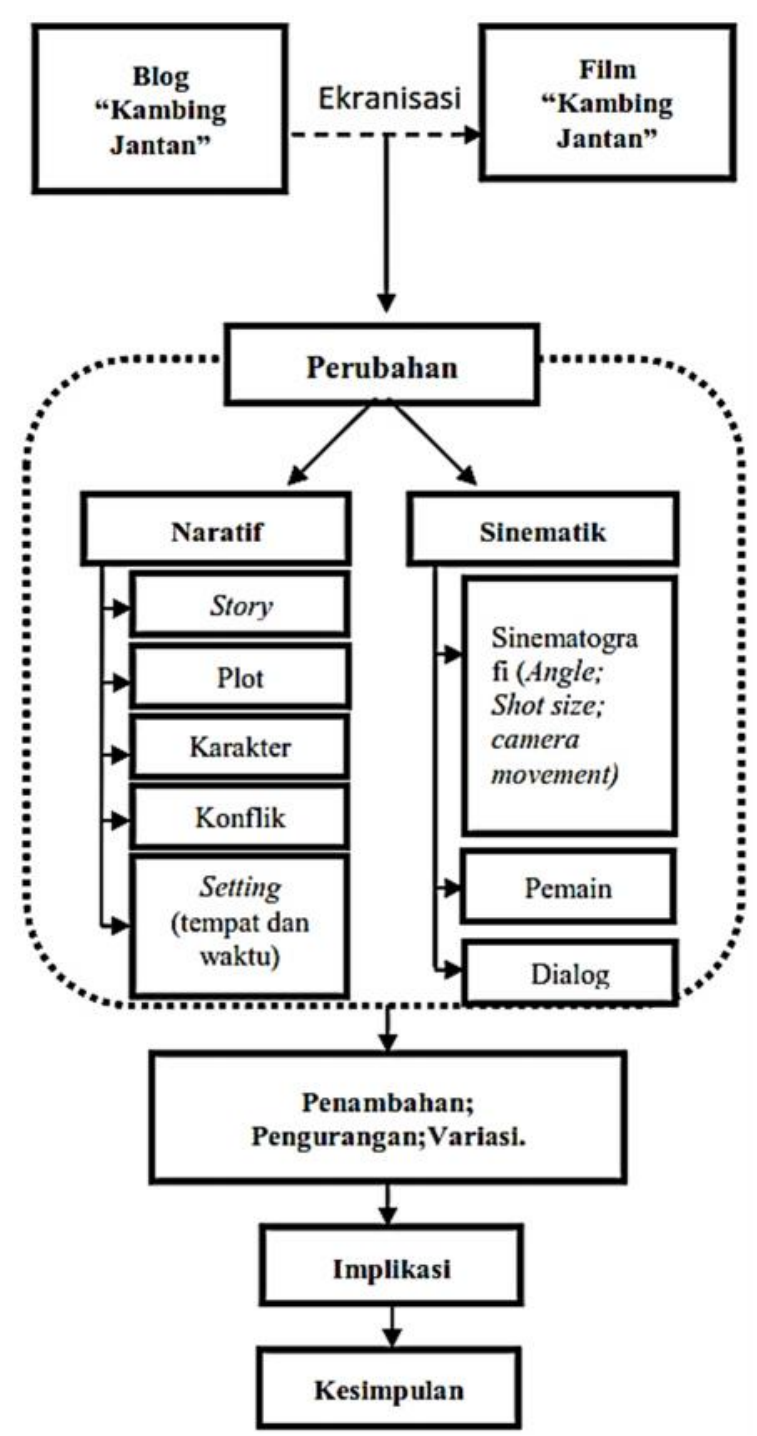

Bagan 1. Skema Penelitian

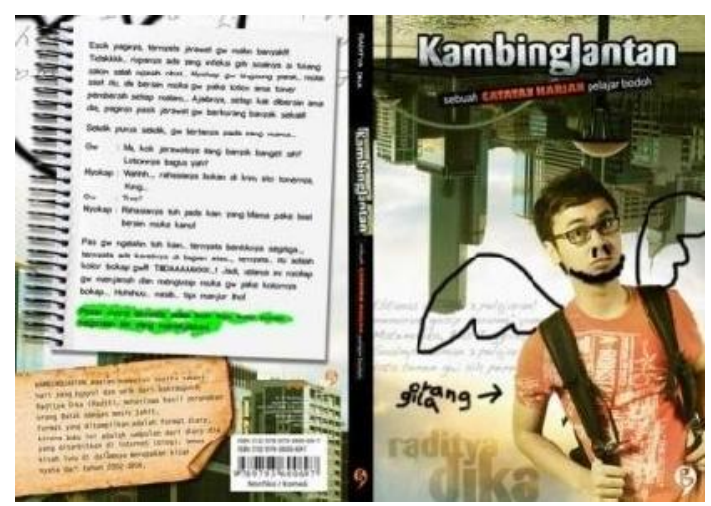

Gambar 1. Cover buku "Kambing Jantan" Catatan Harian Pelajar Bodoh

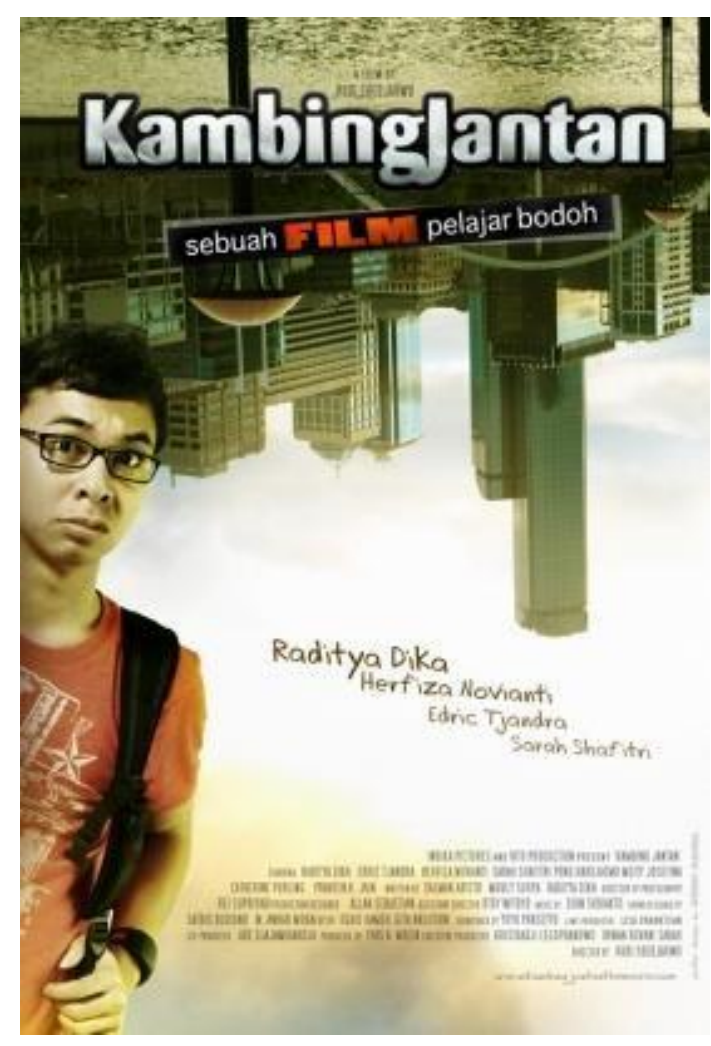

Gambar 2. Cover Film "Kambing Jantan - Sebuah Film Pelajar Bodoh

\section{Objek Penelitian}

Blog "Kambing Jantan" yang digunakan sebagai objek pada penelitian ini berada pada situs kambingjantan.com yang dikelola oleh Raditya Dika. Blog tersebut aktif pada periode tahun 2002 - 2004 . Sumber data yang digunakan pada penelitian ini adalah Buku (kumpulan postingan) "Kambing Jantan - Sebuah Catatan Harian Pelajar Bodoh" yang terbit pada tahun 2005 dan memuat sebanyak 63 judul postingan.

Adapun objek "Kambing Jantan Sebuah Film Pelajar Bodoh" dibuat oleh sutradara Rudi Soedjarwo dengan genre drama komedi. Film ini rilis pada 5 Maret 2009 dengan durasi 118 menit yang memuat 108 scene. 


\section{Landasan Teori}

Teori yang digunakan untuk membaca perubahan pada proses ekranisasi kedua objek di atas merujuk pada pengertian ekranisasi sebagai suatu tindakan mengalihwahanakan dengan cara mengubah bentuk (form) dari sebuah karya ke dalam bentuk lain. Ekranisasi merupakan suatu bentuk adaptasi dengan tujuan utama mengubah wujud karya. Belakangan, adaptasi yang paling banyak dikenal adalah novel ke film. Meski demikian, pada dasarnya adaptasi memiliki makna yang jauh lebih luas.

If you think adaptation can be understood by using novels and films alone, you're wrong. The victorians had a habit of adaptation just about everything - and in just about every possible direction; the stories of foam, novels, plays, operas, paintings, songs, dances, and tableaux vivants were constantly being adapted from one medium to another and then back again. We postmoderns have clearly inherited this same habit... (Hutcheon and O"Flynn 2013, xiii)

Ekranisasi berasal dari kata "ecran" yang dalam bahasa Prancis berarti layar. Ekranisasi dapat diartikan sebagai pelayarputihan, filmisasi, atau pengangkatan karya menjadi film. Proses ekranisasi dari blog "Kambing Jantan" umumnya sama dengan proses ekranisasi karya- karya lain, di dalamnya terdapat proses seleksi yang oleh Bluestone (1957) disebut sebagai penghapusan, penyusutan atau penciutan, dan penambahan.
Eneste (1991: 61-66) dengan merujuk pada Bluestone menjelaskan bahwa perubahan pada proses ekranisasi yaitu penambahan, pengurangan, dan variasi.

Adanya faktor pengurangan, penambahan, dan variasi digunakan untuk melihat perubahan yang terjadi pada proses transformasi dari kumpulan blog menjadi film pada ekranisasi blog "Kambing Jantan".

Terkait ekranisasi atau film adaptasi, unsur naratif dalam cerita merujuk pada tujuh pertanyaan (Krevolin 2003, 15) yang dapat digunakan untuk mengidentifikasi maupun mendefinisikan cerita, yaitu a) Siapa tokoh utamanya? b) Apakah yang diinginkan oleh tokoh utama tersebut? c) Apa/siapa yang menghalangi tokoh utama mendapatkan keinginannya? d) Bagaimana pada akhirnya tokoh utama berhasil mencapai keinginannya dengan cara yang luar biasa, menarik, dan unik? e) Apakah yang ingin disampaikan (oleh pembuat film) dengan mengakhiri cerita seperti ini? f) Bagaimana pembuat film mengisahkan ceritanya? g) Bagaimana tokoh utama dan tokoh-tokoh pendukung mengalami perubahan dalam cerita?

Berdasarkan rujukan tersebut, maka unsur naratif yang dijadikan tolok ukur pada penelitian ini antara lain: Story, Plot, Karakter, Konflik, Setting (ruang dan waktu). Adapun unsur sinematik dalam film 
terdiri dari empat bagian utama yaitu mise en scene, sinematografi, editing, dan suara. Unsur sinematik umumnya merujuk pada bentuk visual dan non- visual.

Bentuk visual adalah sesuatu yang dapat menstimulasi indera penglihat. Pada konsep seni, visual berhubungan dengan penggambaran gagasan dalam bentuk rupa seperti gambar, lukisan, foto, patung, dan lainlain. Wujud visual pada blog umumnya berupa gambar dan foto sebagai ilustrasi pendukung yang menyertai cerita. Sementara wujud visual pada film meliputi unsur-unsur pembentuk sinematik yang dapat dilihat, yaitu mise en scene, sinematografi, dan editing.

Perbandingan bentuk visual blog dan film yang paling mungkin dilakukan pada penelitian ini adalah mise en scene dan sinematografi, karena unsur editing hanya dapat diidentifikasi pada salah satu objek saja yaitu film. Mise en scene mencakup semua hal yang terdapat dalam frame dengan klasifikasi antara lain: Setting (latar), kostum dan tata rias, pencahayaan, serta pemain dan pergerakannya (Pratista 2008, 1). Sementara sinematografi mencakup aspek kamera dan film, framing, dan durasi gambar (Pratista 2008, 89-117). Sinematografi yang digunakan pada penelitian ini adalah framing yaitu shot size dan camera movement.

Bentuk non-visual pada unsur sinematik terdiri dari tiga jenis, yaitu dialog, bahasa bicara, dan aksen (Pratista 2008, 149151). Pratista mendefinisikan dialog sebagai bentuk komunikasi verbal yang digunakan oleh semua karakter baik di dalam maupun di luar cerita. Film dan blog dalam hal ini sama-sama memiliki unsur dialog, sehingga perbandingan pada unsur ini dapat dilakukan.

Berdasarkan uraian di atas, maka unsur sinematik yang digunakan sebagai tolok ukur pada pada penelitian ini adalah sinematografi, pemain, dan dialog.

\section{Pembahasan}

Proses analisis yang dilakukan untuk mencapai tujuan penelitian terdiri dari tiga tahap. Tahap pertama adalah melakukan breakdown (pembedahan) terhadap kedua objek penelitian sehingga diperoleh data yang comparable (dapat dibandingkan).

Tolok ukur perubahan naratif dalam hal ini antara lain, story; plot; karakter; konflik; serta setting (ruang dan waktu). Sementara tolok ukur perubahan sinematik adalah sinematografi; pemain; dan dialog.

Identifikasi perubahan naratif dan sinematik dilakukan dengan membandingkan keseluruhan data dalam wilayah tolok ukur tersebut baik dalam blog maupun film sebagai populasi. Satuan analisis yang digunakan pada masingmasing unsur dalam hal ini berbeda. Mengingat story dan plot merupakan rangkaian peristiwa, maka satuan analisis yang digunakan untuk mengukur perubahannya adalah "peristiwa". Sementara unsur karakter; konflik; setting 


\section{Arami Kasih, Lilik Kustanto, Endang Mulyaningsih}

Implikasi Perubahan Naratif Dan Sinematik Dari Ekranisasi Blog "Kambing Jantan"

(ruang dan waktu); sinematografi; pemain; dan dialog, dianalisis berdasarkan populasi data pada unsur yang bersangkutan. Dengan demikian, proses breakdown dilakukan pada tiap-tiap unsur tersebut.

Tahap kedua adalah mengidentifikasi perubahan naratif dan sinematik yang terjadi sesuai konsep Bluestone dan Eneste yaitu penambahan, pengurangan, dan variasi.

Tahap ketiga adalah melihat implikasi atau dampak langsung dari perubahan naratif dan sinematik yang terjadi. Pada tahap ini, hasil analisis terkait perubahan naratif dan sinematik yang dilakukan berdasarkan penjelasan di atas akan difungsikan sebagai bahan untuk meninjau apa dan bagaimana sebab serta implikasinya. Pengamatan implikasi dalam hal ini tidak hanya sekedar dilakukan terhadap film secara keseluruhan dan menilai seberapa identik kedua objek yang diteliti, tetapi juga secara spesifik membahas bagaimana sebab dan implikasi terjadi pada sesama unsur baik naratif maupun sinematik. Dengan demikian, dapat dilihat apakah perubahan pada salah satu unsur mempengaruhi perubahan pada unsur lain atau sebaliknya, sesuai metode analisis ekranisasi yang diterapkan Bluestone.

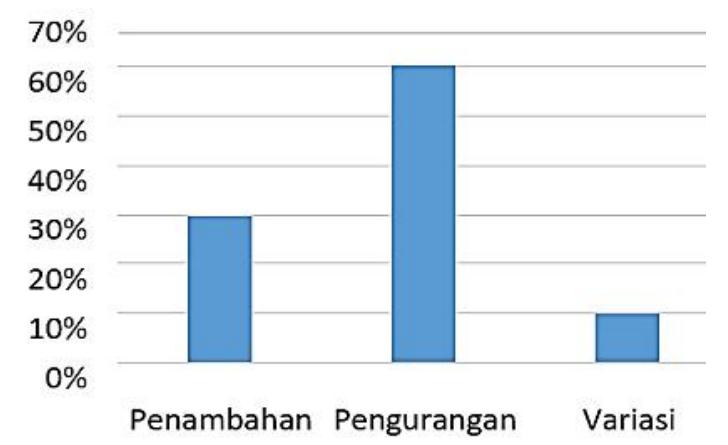

Diagram 1. Perbandingan Bentuk Perubahan Story

\section{Perubahan Naratif}

Story

Pada ekranisasi blog "Kambing Jantan", bentuk perubahan story yang paling banyak terjadi adalah pengurangan. Persentase pengurangan story dalam hal ini mencapai $61 \%$ sementara penambahan story hanya sebesar 29\%, sebagai berikut.

Perubahan story pada kasus ini diikuti perubahan topik yang cukup signifikan. Perbandingan paling mencolok dari penambahan dan pengurangan story adalah pada topik "Keseharian" dan "Cinta". Pada topik “Keseharian" jumlah penambahan sangat sedikit namun pengurangan sangat banyak sementara pada topik "Cinta" terdapat lebih banyak penambahan dibanding pengurangan.

Adapun variasi story terkemas dalam 9 topik dengan 42 peristiwa. Perubahan jenis ini terjadi dalam 4 bentuk yaitu variasi peristiwa, variasi topik, variasi kronologi, dan variasi gabungan. Variasi peristiwa dalam hal ini memuat 4 peristiwa, 2 di antaranya membahas topik "Nama" sementara 2 yang lain membahas “Hewan Peliharaan". Variasi topik dalam hal ini terjadi pada satu peristiwa yaitu topik "Keseharian" pada versi blog berubah menjadi topik "Cinta" dalam versi film. Adapun variasi kronologi terjadi pada 14 peristiwa yang terbagi dalam dua kategori yaitu 7 variasi kronologi tanpa perubahan peristiwa, dan 7 variasi 
kronologi dengan perubahan peristiwa.

Variasi gabungan teridentifikasi pada 2 peristiwa.

\section{Plot}

Perbedaan form objek sebagai blog dan film dalam hal ini memicu perubahan plot secara signifikan. Blog yang merupakan catatan harian umumnya memiliki pola tutur linier. Meski demikian, dalam tinjauan yang lebih spesifik dengan mengamati tiap-tiap postingan, ditemukan beberapa pola linier dan nonlinier. Sementara "Kambing Jantan" versi film hanya memiliki 1 plot yaitu nonlinier.

Perubahan plot dalam hal ini tidak hanya sekedar pengurangan dari banyak mejadi satu, tetapi juga perubahan pola baru. Tangga dramatik Lutters (1) yang digunakan pada "Kambing Jantan" versi film tidak muncul dalam versi blog yang terdiri dari tangga dramatik Aristoteles, Biran, dan lutters (2). Selain itu, versi blog juga dilengkapi dengan postingan-postingan tanpa pola tutur. Perubahan plot dalam hal ini tidak termasuk dalam kategori perubahan manapun, sebab baik blog maupun film memiliki pola bertuturnya sendiri yang berbeda.

\section{Karakter}

Bentuk perubahan yang paling banyak dilakukan pada unsur karakter adalah pengurangan yaitu $58 \%$, disusul bentuk penambahan sebanyak $29 \%$, dan bentuk variasi sebanyak $11 \%$.

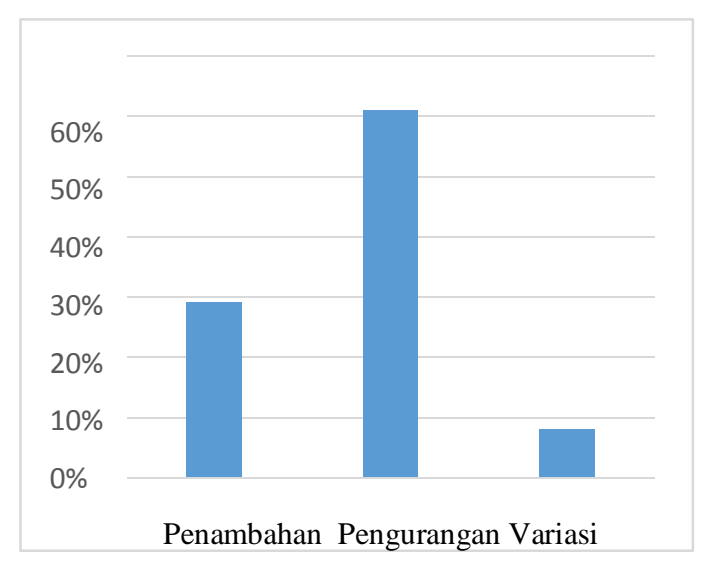

Diagram 2. Perbandingan Bentuk Perubahan Karakter

Bentuk pengurangan paling banyak dalam hal ini terdapat pada jenis karakter teman di Australia yang berbanding terbalik dengan bentuk penambahan pada jenis yang sama. Adapun pada jenis petugas/pelayan, perubahan dalam bentuk penambahan lebih banyak daripada pengurangan. Sementara pada kategori jenis karakter orang asing, bentuk pengurangan lebih banyak daripada bentuk penambahan. Pada jenis Teman di Indonesia, penambahan dan pengurangan tampak hampir sebanding. Hal ini terjadi pula pada jenis guru dan tokoh terkenal. Terdapat pula jenis karakter baru yang sama sekali tidak muncul pada versi blog yaitu Teman pacar, pacar, kru film, dan keluarga pacar. Hal ini terjadi juga pada pengurangan. Karakter yang sama sekali tidakmuncul pada versi film adalah karakter fantasi, peliharaan, anggota keluarga, teman chating, hewan liar, dan ibu teman.

\section{Konflik}

Perubahan konflik paling banyak adalah pengurangan yaitu $69 \%$, disusul penambahan konflik sebanyak $21 \%$ dan 
variasi 5\%. Penambahan, pengurangan, serta variasi tersebut terjadi dalam kategori Dika dengan pacar, Dika dengan keluarga, Dika dengan alam, Dika dengan diri sendiri, dan Dika dengan teman.

Penambahan konflik paling banyak terdapat pada kategori Dika dengan pacar. Pengurangan paling dominan terdapat pada kategori Dika dengan alam dan Dika dengan diri sendiri. Perbandingannya sebagai berikut.

\section{Setting (ruang dan waktu)}

Bentuk perubahan yang paling banyak terjadi pada setting ruang adalah Pengurangan yaitu $51 \%, 21 \%$ penambahan, dan $8 \%$ variasi.

Perbandingan perubahan paling signifikan adalah pengurangan ruang tempat tinggal. Terdapat pula jenis tempat yang sama sekali tidak mengalami penambahan seperti Restoran, Tempat hiburan, Ruang maya, Toko, Bandara, dan Penginapan. Selain itu, ditemukan pula jenis tempat yang baru muncul dalam versi film yaitu tempat kerja.

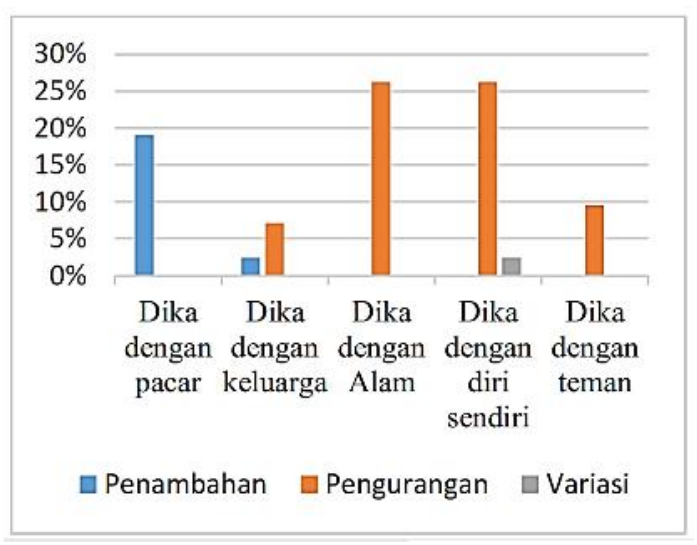

Diagram 3. Perbandingan Perubahan Konflik Berdasarkan Kategori
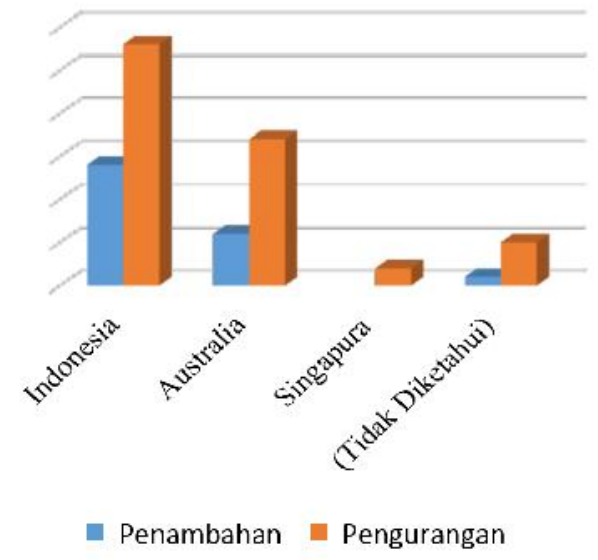

Diagram 4. Perbandingan Bentuk Perubahan Setting ruang berdasarkan letak geografis

Perubahan tersebut, berdasarkan letaknya secara geografis memiliki perbandingan sebagai berikut. Bentuk variasi dalam hal ini tidak dapat dibandingkan secara geografis karena mengalami perubahan.

Adapun pada setting waktu, perubahan dalam bentuk penambahan terjadi pada komponen durasi story dan plot, sebagai berikut.

Tabel 1. Bentuk Penambahan Durasi

\begin{tabular}{crc}
\hline Durasi & \multicolumn{1}{l}{ Story } & Plot \\
\hline Blog & 13 tahun & 2 tahun \\
Film & 25 tahun & 25 tahun \\
\hline
\end{tabular}

Pengurangan dalam hal ini terjadi sebagai bentuk pemampatan waktu dengan menyusutnya periode masa-masa tertentu, sebagai berikut. 


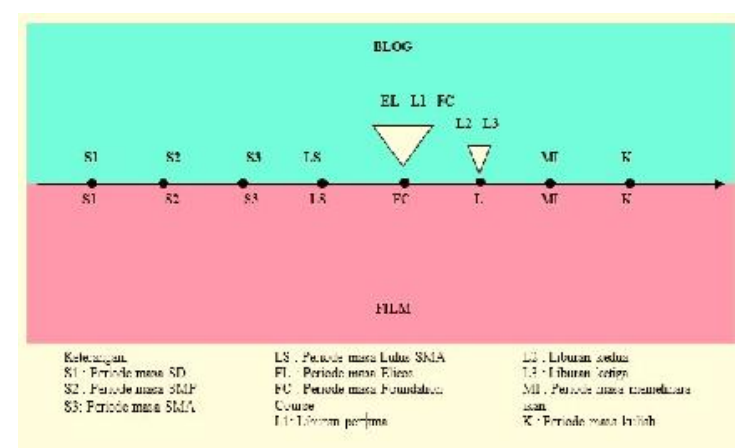

Bagan 2. Bentuk Pengurangan Waktu

Adapun bentuk variasi terdapat pada komponen order, sebagai berikut.

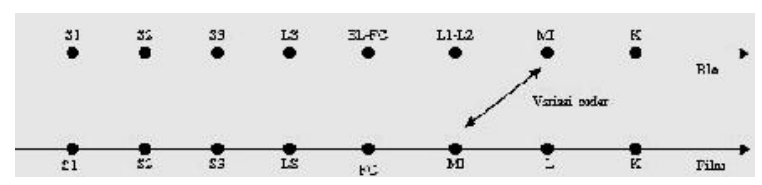

Bagan 3. Bentuk variasi Order

\section{Perubahan Sinematik}

\section{Sinematografi}

Perubahan sinematografi terdiri dari 1 penambahan gambar, 2 penambahan shot size, 2 penambahan angle, 1 penambahan movement, 1 pengurangan gambar, 2 variasi bentuk visual, 2 variasi komponen gambar, 2 variasi angle, dan 3 variasi shot size.

Dengan demikian, perbandingan perubahan unsur sinematografi adalah sebagai berikut.

\section{Pemain}

Penambahan pemain pada ekranisasi dari blog ke film pada film "Kambing Jantan" adalah Yeyen, Edric Tjandra, Herfiza Novianti, Meity Josefina, Geoffrey Yu, Heintje Lawalata, Pong Hardjatmo, Ikan mas, Chatrine Purling, Theodora Fauzia, dan Akinori Yamamoto. Sementara itu, pengurangan pemain dilakukan pada tokoh pembantu- pembantu Dika, Harianto, Kebo, Mama dika (Nasution), Mingu, Orang asing homo, Papa Dika (Nasution), Ikan mas, Sally Dickson, Takuji, Bryan, dan Ovan Lumi.

Selain penambahan dan pengurangan di atas, pada "Kambing Jantan" versi blog dan film juga ditemukan kemunculan tokoh yang populer di mata publik atau yang biasa dikenal dengan sebutan cameo (Pratista 2008, 82-84). "Kambing Jantan" versi blog dalam hal ini menghadirkan tokoh Ruhut Sitompul yang lebih dikenal sebagai Poltak (peran yang dimainkannya dalam serial Gerhana). Di masyarakat, Poltak dikenal sebagai pengacara, pemain sinetron, dan politikus. Kemunculan Poltak dalam blog terdapat pada peristiwa Radith dijemput oleh keluarganya di bandara.

Pada “Kambing Jantan” versi film, cameo yang digunakan adalah Ian Kasela dan Rudy Soedjarwo. Di mata masyarakat, Ian Kasela adalah seorang vokalist band yang cukup populer pada tahun 2004 hingga 2009 yaitu Radja. Kemunculannya terdapat pada peristiwa Dika mencaritahu arti LDR. Sementara itu, Rudy Soedjarwo sebagai sutradara film "Kambing Jantan" sendiri, mulai populer di masyarakat sejak karya film Ada Apa dengan Cinta yang rilis pada tahun 2002. Kemunculan Rudy Soedjarwo terdapat pada akhir film.

Dengan demikian diketahui bahwa perubahan unsur pemain melingkupi 


\section{Arami Kasih, Lilik Kustanto, Endang Mulyaningsih}

Implikasi Perubahan Naratif Dan Sinematik Dari Ekranisasi Blog "Kambing Jantan"

penambahan pemain aktor sebanyak 13 dan pengurangan pemain asli sebanyak 11 . Adapun, bentuk variasi terletak pada penggunaan cameo.

\section{Dialog}

Perubahan dialog paling banyak adalah bentuk penambahan. Persentase perubahan dalam bentuk variasi dalam hal ini $5 \%$ lebih sedikit dari penambahan. Adapun perubahan dalam bentuk pengurangan adalah yang paling sedikit. Perubahan dialog dalam hal ini terjadi pada dua kategori peristiwa yaitu peristiwa yang mengalami variasi dan yang tidak mengalami variasi. Penambahan dialog dalam peristiwa yang mengalami variasi lebih banyak daripada penambahan dalam peristiwa yang tidak memiliki variasi.

Hal ini serupa dengan variasi dialog dimana perubahan lebih banyak terjadi pada peristiwa yang mengalami variasi. Sementara pengurangan dialog hanya terjadi pada peristiwa yang tidak mengalami variasi. Rinciannya sebagai berikut.

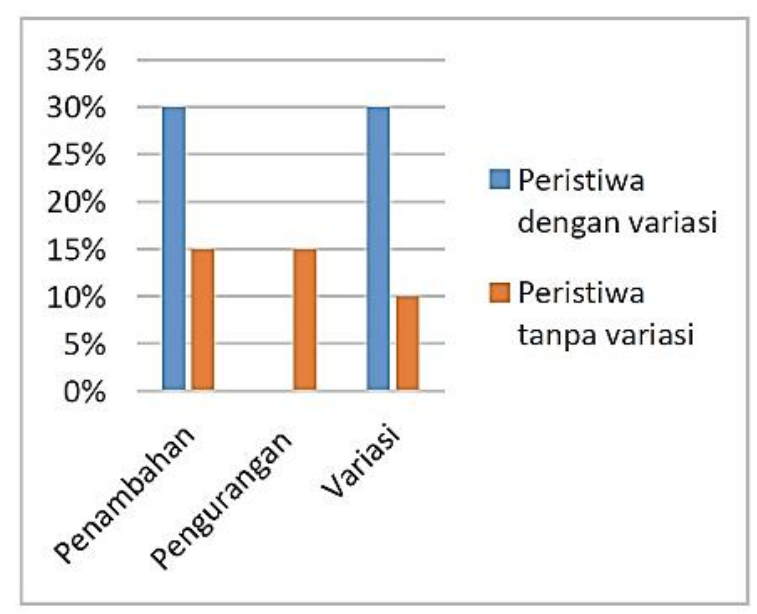

Diagram 5. Perbandingan Bentuk Perubahan Dialog Berdasarkan Variasi Peristiwa

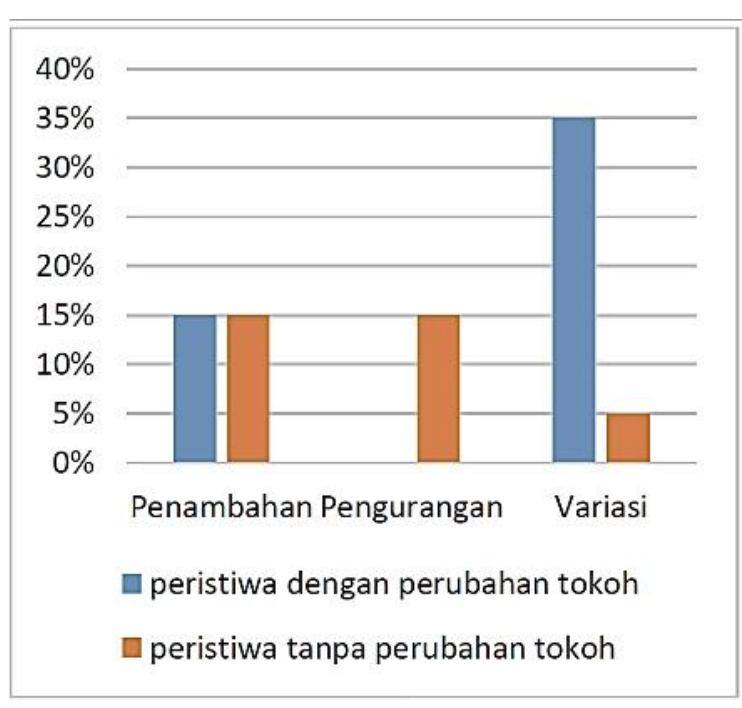

Diagram 6. Perbandingan Bentuk Perubahan Dialog Berdasarkan Perubahan Tokoh

\section{Implikasi Perubahan}

Perubahan naratif dan sinematik dari ekranisasi blog "Kambing Jantan" memiliki sebab dan implikasi tertentu. Merujuk pada pendapat Woodrich (et al. 2016) terkait penelitian ekranisasi yang menggunakan teori Bluestone (lihat Bab 3), implikasi perubahan naratif dan sinematik pada penelitian ini diamati melalui dua cara yaitu pengamatan implikasi secara khusus, dan pengamatan implikasi secara umum.

Pengamatan implikasi khusus dalam hal ini berada pada koridor naratif dan sinematik saja, tanpa melihat bagaimana implikasinya terhadap film secara keseluruhan. Pengamatan ini dilakukan guna meninjau bagaimana perubahan pada unsur-unsur naratif dan sinematik mempengaruhi perubahan pada unsur lain. Dengan demikian dapat diketahui bagaimana pola hubungan sebab-akibat dari tiap-tiap perubahan pada unsur naratif dan sinematik. 
Adapun pengamatan implikasi umum difungsikan untuk melihat bagaimana perubahan naratif dan sinematik mempengaruhi objek hasil yaitu film. Bentuk analisis dalam hal ini berada pada lingkup kelebihan, kekurangan, serta keunikannya sebagai manifestasi gagasan dalam bentuk lain.

Perubahan naratif dalam transformasi bentuk blog menjadi film pada "Kambing Jantan" terdiri dari perubahan story, plot, karakter, konflik, dan setting. Perubahan tersebut diidentifikasi melalui bentuk penambahan, pengurangan, dan variasi. Adapun perubahan mendasar yang terjadi dalam proses ekranisasi dari blog ke film adalah perubahan story.

Perbedaan ciri serta sifat objek pada blog dan film "Kambing Jantan" mempengaruhi perubahan teks dan konteks yang secara berkesinambungan membentuk pola tertentu dalam hubungan sebab dan implikasi. Dengan demikian, setiap perubahan yang terjadi dalam proses ekranisasi memiliki sebab dan implikasi tertentu yang dapat berupa perubahan lain yang juga memiliki sebab dan implikasi lain.

Hubungan sebab dan implikasi perubahan naratif pada ekranisasi blog "Kambing Jantan" dalam hal ini tidak hanya terjadi pada ruang naratif saja. Akan tetapi perubahan naratif juga memiliki implikasi terhadap perubahan shot size dan angle, perubahan pemain, serta perubahan dialog.
Dalam ekranisasi dari blog ke film pada "Kambing Jantan", perbedaan antara story versi blog dan versi film cukup signifikan. Perbedaan ini dapat dipengaruhi oleh banyak faktor dimana beberapa di antaranya adalah ciri dan sifat objek, jenis dan fungsi objek, keputusan si pembuat film, dan bahkan target audiens.

Penambahan dan pengurangan story pada ekranisasi blog "Kambing Jantan" terjadi secara signifikan dan random. Signifikansi perubahan jumlah story dalam hal ini menuntut perubahan plot yang juga signifikan. Perbedaan jumlah peristiwa dengan rincian penambahan dan pengurangan yang mencolok memiliki dampak langsung yang cukup besar terhadap plot.

Story pada ekranisasi "Kambing Jantan" diketahui memiliki kondisi awal yang terdiri dari rangkaian kumpulan peristiwa dalam story dengan judul dan topik tertentu dimana tiap-tiap story memiliki pola bertuturnya sendiri. Perubahan story dari banyak menjadi satu memiliki dampak yang cukup signifikan terhadap perubahan pola tutur. Adanya bentuk penambahan, pengurangan, dan variasi dalam hal ini memungkinkan story pada hasil ekranisasi memiliki pola bertutur yang sama sekali berbeda dengan pola bertutur semula.

Blog “Kambing Jantan” sebagai buku harian diketahui secara garis besar 


\section{Arami Kasih, Lilik Kustanto, Endang Mulyaningsih}

Implikasi Perubahan Naratif Dan Sinematik Dari Ekranisasi Blog "Kambing Jantan"

membentuk pola bertutur linier yang terdiri dari pola-pola linier dan non-linier. Sementara "Kambing Jantan" versi film tersusun dalam satu plot non-linier saja.

Pada proses ekranisasi, peristiwa dari 63 postingan blog diangkat secara acak untuk kemudian disatukan dalam sebuah kelompok peristiwa lain yang memiliki hubungan sebabakibat. Blog "Kambing Jantan" dalam hal ini diangkat dengan mengesampingkan batasan judul pada postingan-nya sehingga pada proses pengangkatan, plot pada blog ikut hilang. Peristiwa-peristiwa yang diangkat kemudian membentuk plot baru bersama peristiwa yang muncul sebagai bentuk penambahan. Pada tahap selanjutnya, perubahan plot secara berkesinambungan berimplikasi pada perubahan setting waktu dan perubahan konflik.

Perubahan setting waktu diketahui terdiri dari penambahan durasi yang merupakan implikasi penambahan story dan perubahan plot. Adapun proses pemampatan sebagai bentuk pengurangan setting waktu merupakan implikasi dari pengurangan rangkaian peristiwa dalam periode terkait. Selain itu, variasi order yang mewakili bentuk variasi waktu merupakan implikasi dari adanya penambahan dan pengurangan peristiwa pada story dan perubahan plot.

Dalam kaitannya dengan konflik, perubahan topik pada story umumnya memicu perubahan kategori dan jenis konflik sementara perubahan plot berdampak pada perubahan jumlah konflik. Penambahan peristiwa dalam topik "Cinta" berdampak langsung pada penambahan konflik dalam kategori Dika dengan pacar yang sekaligus menambah jenis konflik eksternal. Sementara pengurangan topik "Keseharian" berdampak langsung terhadap pengurangan konflik Dika dengan alam serta Dika dengan diri sendiri yang sekaligus mengurangi jenis konflik internal.

Adapun perubahan plot dalam hal ini disertai perubahan tangga dramatik sehingga memiliki dampak langsung terhadap perubahan konflik. Pada "Kambing Jantan" versi blog diketahui terdapat 3 pola tangga dramatik yaitu Biran, Elizabeth lutters 2, dan Aristoteles. Dalam versi film pola yang tersusun adalah tangga dramatik Elizabeth Lutters 1. Perubahan plot dan tangga dramatik mempengaruhi perubahan konflik baik dari segi jumlah maupun variasinya.

Mengingat data story pada versi blog tidak tersusun dalam sebuah kronologi peristiwa yang memiliki hubungan sebabakibat yang eksplisit, maka perubahan story dalam hal ini tidak mengikuti pola atau aturan tertentu. Sehingga, analisis penambahan, pengurangan, dan variasi peristiwa dilakukan dalam lingkup perbandingan topik.

Pada penambahan story ditemukan topik sebanyak 18, sementara pada pengurangan story sebanyak 28. Pada 
penambahan dan pengurangan tersebut, terdapat 4 penambahan topik baru yaitu “Keuangan", “Cita-cita”, “Syuting”, dan "Bule"; serta penghilangan topik sebanyak 11, yaitu “Kesehatan”, “Tempat makan”, “Film”, "Hobi”, “Supranatural”, "Perbedaan bahasa”, “Politik”, “Teknologi”, “Bahasa Inggris”, "Fantasi", dan "Musik".

Penambahan pada story berimplikasi terhadap perubahan karakter yang kemudian berdampak pada perubahan setting ruang dan konflik. Penambahan topik "Cinta" pada story memicu penambahan jenis karakter pacar, teman pacar, keluarga pacar, serta penambahan orang asing, petugas/pelayan, dan guru dalam lingkup peristiwa relevan. Penambahan karakter tersebut secara berkesinambungan berdampak pada penambahan setting ruang dan konflik.

Perubahan karakter sebagai implikasi perubahan story juga mempengaruhi perubahan setting ruang. Perubahan karakter baik penambahan, pengurangan, maupun variasi mengimplikasikan perubahan setting ruang. Adanya karakter baru dalam versi film otomatis menambah setting ruang dalam story.

Topik "Keuangan" dalam hal ini menjadi topik dengan penambahan peristiwa terbanyak urutan ke-3 dengan persentase 3\%. Penambahan topik "Keuangan" berimplikasi pada penambahan karakter pada peristiwa dalam topik terkait.

Perubahan lain yang cukup signifikan sebagai dampak perubahan story adalah perubahan sinematografi, perubahan pemain, dan perubahan dialog. Perbandingan bentuk visual dalam sinematografi pada penelitian ini dipengaruhi oleh perubahan story, sehingga gambar pada story yang hilang sama sekali tidak muncul dalam bentuk film. Sementara pada unsur dialog, perubahan bentuk penambahan dan variasinya hanya terjadi pada peristiwa yang mengalami variasi dimana sebagian besar perubahan dialog terletak pada peristiwa yang memiliki perubahan tokoh di dalamnya.

Ditinjau dari cakupan lebih luas, perubahan naratif pada ekranisasi dari blog “Kambing Jantan” umumnya membentuk struktur narasi dengan isu baru. Berdasarkan perbandingan perubahan topik dalam story, ditemukan bahwa penambahan paling banyak terdapat pada topik "Cinta" sementara pengurangan paling banyak terdapat pada topik "Keseharian". Dengan demikian, diketahui bahwa pada ekranisasi dari blog "Kambing Jantan" terdapat usaha mengubah orientasi story dari sekedar story keseharian menjadi story cinta.

Adapun bentuk implikasi lain dari perubahan naratif adalah story menjadi lebih singkat, padat, dan memiliki hubungan sebab-akibat yang eksplisit; Hilangnya kesan buku harian; Perubahan selera humor; Story menjadi lebih fokus karena karakter dan konflik menjadi lebih sedikit; Penggunaan setting lokasi sedikit. 
Adapun perubahan sinematik terdiri dari perubahan sinematografi, perubahan pemain, dan perubahan dialog. Perubahan sinematik dalam hal ini merupakan implikasi dari perubahan naratif dan sifat media. Film "Kambing Jantan" sebagai bentuk akhir transformasi termuat dalam media audiovisual dengan sajian gambar dan suara. Hal ini sangat berbeda dengan sajian tulisan dan gambar pada media blog.

Perbandingan bentuk perubahan pada sinematografi adalah 9 variasi, 6 penambahan, dan 1 pengurangan. Adapun perubahan pemain terdiri dari pengurangan dan penambahan 11 pemain. Sementara perubahan dialog terdiri dari $45 \%$ penambahan, $40 \%$ variasi dan $15 \%$ pengurangan.

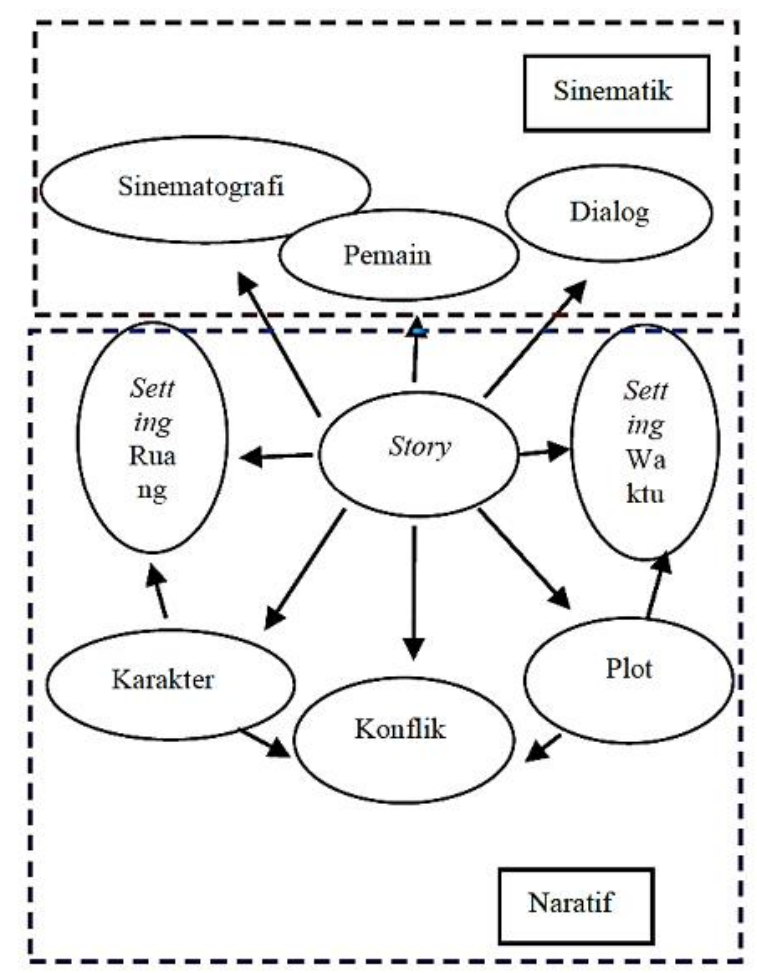

Bagan 4. Pola Implikasi Perubahan dalam ekranisasi Blog "Kambing Jantan"

\section{Kesimpulan}

Ditinjau dari seberapa identik objek awal dengan hasil ekranisasi, signifikansi perubahan pada kasus ini menandai bahwa blog dan film "Kambing Jantan" merupakan dua karya yang pada dasarnya berbeda. Pengangkatan gagasan dalam hal ini hanya terjadi pada ikon-ikon tertentu yang dianggap krusial, seperti nama blog "Kambing Jantan"; identitas tokoh utama sebagai "pelajar bodoh", karakter Raditya Dika dan orang-orang terdekatnya; setting ruang dan waktu secara umum; serta peristiwa-peristiwa tertentu yang relevan.

Perubahan yang terjadi dalam ekranisasi blog "Kambing Jantan" secara naratif dan sinematik adalah penambahan, pengurangan, dan variasi unsur story; karakter; konflik; setting ruang dan waktu; sinematografi; pemain; dan dialog. Adapun pada unsur plot, perubahan tidak terjadi secara penambahan, pengurangan, maupun variasi tetapi tetap mengalami perubahan.

Adapun implikasi perubahan naratif dan sinematik dari ekranisasi blog “Kambing Jantan" terjadi secara khusus dan umum. a) Implikasi khusus : Implikasi ini dimulai dengan perubahan story yang kemudian berdampak pada perubahan seluruh unsur lain dalam wilayah naratif dan sinematik baik secara langsung maupun melalui perantara. Ketika story berubah, maka plot ikut berubah. Ketika plot berubah, maka setting (waktu) dan konflik ikut 
berubah. Adapun implikasi perubahan story pada karakter memicu perubahan setting ruang dan perubahan konflik. b) Implikasi umum : Cerita menjadi lebih singkat, padat, dan memiliki hubungan sebab-akibat yang eksplisit; Hilangnya kesan buku harian; Cerita menjadi lebih fokus karena karakter dan konflik menjadi lebih sedikit; Penggunaan setting lokasi lebih sedikit; Perubahan sinematik dalam hal ini memberi kesan lebih komunikatif dengan penggambaran adegan yang lebih jelas dan real.

\section{Daftar Pustaka}

Bluestone, George. Novels into film. Barkeley: University of California Press, 1957.

Boggs, Joseph M, dan Dennis W. Petrie. The Art of Watching Films. New York: McGraw-Hill, 2008.
Damono, Sapardi Djoko. Sastra Bandingan. Jakarta: Editum, 2009.

Dika, Raditya. Kambing Jantan - Sebuah Catatan Harian Pelajar Bodoh. Jakarta: Gagas Media, 2005.

Eneste, Pamusuk. Novel dan Film. Flores: Nusa Indah, 1991.

Hutcheon, Linda dan Siobhan O'Flynn. A Theory of Adaptation (Second Edition). New York : Routledge, 2013

Krevolin, Richard. How to Adaptation Anything into a Screenplay. Bandung: PT. Mizan Pustaka. 2003

Pratista, Himawan. Memahami Film. Yogyakarta: Homerian Pustaka, 2008.

Sugiono. Metode Penelitian Kuantitatif, Kualitatif, dan R \&D. Bandung: Alfabeta, 2011. 